\title{
Association of leptin receptor genetic variants (LEPR) with obesity and leptin level in unexplained infertility in northern Indian population
}

\author{
Pratibha Kumari $^{\mathrm{a}}$, Swati Gautam ${ }^{\mathrm{a}}$, S.P. Jaiswar ${ }^{\mathrm{a}, *}$, P.L. Shankhwar ${ }^{\mathrm{a}}$, Mohd Kalim Ahmad ${ }^{\mathrm{b}}$, \\ Abbas Ali Mahdi ${ }^{\mathrm{b}}$ \\ ${ }^{a}$ Dept.of Obstetrics and Gynaecology, KGMU, Lucknow, India \\ ${ }^{\mathrm{b}}$ Dept. of Biochemistry, KGMU, Lucknow, India
}

\section{A R T I C L E I N F O}

\section{Keywords:}

BMI

RFLP

Unexplained infertility

Obesity

Leptin

\begin{abstract}
A B S T R A C T
Background: The leptin receptor (LEPR) gene, is a member of the class I cytokine receptor superfamily, with six known isoforms. Animal as well as human modal both studies indicate that LEPR have important and powerful roles in the mechanism of obesity. This study aims to determine the correlation of the LEPR genetic variant with obesity and leptin level in the obese and control groups in the northern Indian population.

Methods: 109 fertile controls and 120 unexplained infertile cases were recruited. Serum leptin level was measured by active human ELISA kit using an ELISA reader. Leptin receptor gene polymorphism A668G, A326G and G1968C were analyzed by polymerase chain reaction (PCR) followed by restriction fragment length polymorphism (RFLP).

Results: The anthropometric parameters are slightly higher in obese cases as compared to control group ( $p>0.005)$, whereas waist circumference and hip circumference shows a significant $p-$ value $(p<0.005)$ between obese cases and controls. The leptin level is found increased in obese cases than controls and this difference is significant with $\mathrm{p}<0.05$. The higher frequency of GG genotype of (Gln223Arg) variant in obese cases with significant difference found in between obese cases and control groups $\mathrm{p}<0.001$. Similarly GG and CC genotype of (Lys109Arg) and (Lys656Asn) respectively found higher frequency with significantly different $\mathrm{p}<0.001$ in obese group as compared to control group.

Conclusion: Genetic variants (Gln223Arg), (Lys109Arg) and (Lys656Asn) in LEPR gene are significantly associated with anthropometric parameter obesity and leptin level in northern Indian population.
\end{abstract}

\section{Introduction}

An abnormal increase of fat in the subcutaneous connective tissue defined as obesity. It is the outcome of an interaction between genetic and environmental factors. ${ }^{1,2}$ In genetic factors, one of the variations at the leptin receptors (LEPR) genes are responsible for the morbid obesity in mouse models as well as in some cases of obesity in humans. ${ }^{3}$ The adipose tissue-derived hormone leptin is produced in proportion to fat stores. ${ }^{4}$ Leptin levels permit energy expenditure in many processes like reproduction, growth, autonomic nervous system, endocrine and immune system. ${ }^{5,6}$ Animal as well as human modal both studies indicate that LEPR have important and powerful roles in the mechanism of obesity. ${ }^{7}$ The sequence variants for LEPR gene has been screened in many studies, but mutation that associated with obesity have not been reported. ${ }^{8,9}$ Gene of leptin receptor is located on the chromosome of
1 p31 in human and has five isoforms. ${ }^{9-11}$ LEPR has two main isoform i.e., long arm and short arm isoform due to changes in length of the cytoplasmic domain, but in human four isoforms were identified; one is long isoform with 1165 amino acid responsible for leptin signaling and rest 3 are splicing short isoforms. ${ }^{12}$ Defects in leptin production cause severe obesity. ${ }^{13}$ Leptin receptor is located in adipose tissue, stomach, endometrium, liver, spleen, and placenta. Leptin receptor acts via negative feedback between its concentration in blood serum and its receptors expression on the cell surface. ${ }^{14}$ Plasma leptin levels are closely correlated with the amount of adipose tissue. ${ }^{15}$ Reproductive function is also depends on the energy reserves stored as fat in adipose tissue as other physiological functions. ${ }^{16}$

This study aims to determine the correlation of the LEPR genetic variants with obesity and leptin level in the obese and control groups in the northern Indian population.

\footnotetext{
* Corresponding author.

E-mail addresses: kgmu.prati2011@gmail.com (P. Kumari), swatigautam.bio@gmail.com (S. Gautam), spjaiswar59@gmail.com (S.P. Jaiswar), sankhawar_pushpa@yahoo.co.in (P.L. Shankhwar), kaleembaksh@gmail.com (M.K. Ahmad), mahdiaa@rediffmail.com (A.A. Mahdi).
} 


\section{Subjects and methods}

\subsection{Subjects}

This case-control study was approved by institutional ethics committee (ref no-53ECMIIB/P1) of King George's Medical University, Lucknow. The work has been done in the Department of Obs \& Gynae K.G.M.U Lucknow. Subjects (Cases \& Control) were recruited under following inclusion and exclusion criteria. Inclusion criteria: (Case)Age group between 18 and 40 years, Infertile female with BMI for A 1 group $\geq 25$ and for A2 group $18<25$, Females having unexplained infertility of at least one year. Controls- Age group 18-40 years, Healthy subject with BMI for B1 group- $\geq 25$ and for B2 group18 $<25$, Female having at least one conception. Exclusion criteria (Case)Pregnancy, Subjects with any endocrinal disorders, diabetes mellitus, chronic illness like genital tuberculosis, Su any chronic medication, mullerian anomalies. (Controls)- Subjects on hormonal contraception within last one year, any illness, endocrinal disorder, autoimmune/ immunocompromised condition and taking chronic medication. Informed consent was obtained from each subject. The 229 female were included in the study, of which 109 fertile controls and 120 unexplained infertile cases were recruited from Out Patient Door (OPD) of Department of Obs \& Gynae K.G.M.U Lucknow. Total $5 \mathrm{ml}$ venous blood were collected from enrolled subjects, $3 \mathrm{ml}$ for serum vile and $2 \mathrm{ml}$ in EDTA vile for DNA isolation. Serum leptin level was measured by active human ELISA kit using an ELISA reader.

\subsection{Anthropometric, biochemical and leptin level}

The anthropometric data of two groups is summarized in Table-1. Age matched (19-41) year healthy control and case enrolled in the study. Body weight $(\mathrm{Kg})$, height $(\mathrm{m}), \mathrm{BMI}\left(\mathrm{kg} / \mathrm{m}^{2}\right)$, waist $(\mathrm{cm})$ and hip $(\mathrm{cm})$ circumference were measure a calibrated scale.

\subsection{LEPR genes genotyping}

Genomic DNA was extracted by using Phenol-Chloroform method from $2 \mathrm{ml}$ blood collected in EDTA vile. Approx. $50 \mathrm{ng}$ of the DNA was used for each PCR reaction. Leptin receptor gene polymorphism Gln223Arg, Lys109Arg and Lys656Asn were analyzed by polymerase chain reaction (PCR) followed by restriction fragment length polymorphism (RFLP). Genomic DNA was amplified by PCR Thermocycler (Applied Biosystems, Germany) using following PCR conditions: $94^{\circ} \mathrm{C}$ for $4 \mathrm{~min}, 35$ cycles at $94^{\circ} \mathrm{C}$ for $30 \mathrm{~s}, 58^{\circ} \mathrm{C}$ for $40 \mathrm{~s}, 72^{\circ} \mathrm{C}$ for $40 \mathrm{~s}$, and finally $72{ }^{\circ} \mathrm{C}$ for $8 \mathrm{~min}$ for $\mathrm{Gln} 223 \mathrm{Arg}$ variant, $95^{\circ} \mathrm{C}$ for $5 \mathrm{~min}, 31$ cycles at $94^{\circ} \mathrm{C}$ for $30 \mathrm{~s}, 58^{\circ} \mathrm{C}$ for $30 \mathrm{~s}, 72^{\circ} \mathrm{C}$ for $40 \mathrm{~s}$, and finally $72^{\circ} \mathrm{C}$ for $6 \mathrm{~min}$ for Lys109Arg variant and $94^{\circ} \mathrm{C}$ for $4 \mathrm{~min}, 30$ cycles at $94^{\circ} \mathrm{C}$ for $30 \mathrm{~s}$, $58^{\circ} \mathrm{C}$ for $40 \mathrm{~s}, 72^{\circ} \mathrm{C}$ for $40 \mathrm{~s}$, and finally $72^{\circ} \mathrm{C}$ for $8 \mathrm{~min}$ for Lys656Asn variant. The primers used for amplification of LEPR gene Gln223Arg, Lys109Arg and Lys656Asn polymorphism are as follows: (i) forward primer 5'- AGTTCAAATAGAGGTCCAAATCA-3' and reverse primer 5' TTCTGAGGTTGTGTCACTGGCA-3'(ii) forward primer $5^{\prime}$ - AGTTCAAAT AGAGGTCCAAATCA-3'and reverse primer 5'- TTCTGAGGTTGTGTCAC TGGCA-3', (iii) forward primer 5'-AGTTCAAATAGAGGTCCAAATCA3 'and reverse primer 5'-TTCTGAGGTTGTGTCACTGGCA -3' respectively. The PCR results for Gln223Arg, Lys109Arg and Lys656Asn Polymorphism were determined by the digestion of PCR product for 18hr using MspI HaeIII and AccII enzymes (NEB, UK) for Gln223Arg, Lys109Arg and Lys656Asn respectively. Gel electrophoresis with 3\% agarose was performed to analyze the digestion.

\subsection{Data analysis}

Continuous data were summarized as Mean \pm SD while discrete (categorical) in no. and percentage. Continuous groups were compared by independent Student's $t$-test while categorical by chi-square $\left(\chi^{2}\right)$ test.
Table 1

Anthropometric characteristics and leptin level in the obese and control group.

\begin{tabular}{lllll}
\hline S. No. & Variables & Controls $(\mathrm{n}=109)$ & Cases $(\mathrm{n}=120)$ & p-value \\
\hline $\mathbf{1 .}$ & Age (yrs) & $29.58 \pm 4.01$ & $29.53 \pm 4.43$ & 0.925 \\
$\mathbf{2 .}$ & Height $(\mathrm{cm})$ & $145.78 \pm 6.58$ & $147.39 \pm 6.69$ & 0.067 \\
$\mathbf{3 .}$ & Weight $(\mathrm{kg})$ & $51.54 \pm 6.90$ & $52.29 \pm 8.92$ & 0.480 \\
$\mathbf{4 .}$ & BMI $\left(\mathrm{kg} / \mathrm{m}^{2}\right)$ & $24.31 \pm 3.19$ & $24.10 \pm 3.90$ & 0.671 \\
$\mathbf{5 .}$ & WC $(\mathrm{cm})$ & $82.95 \pm 9.64$ & $95.65 \pm 10.99$ & $<\mathbf{0 . 0 0 1}$ \\
$\mathbf{6 .}$ & HC $(\mathrm{cm})$ & $91.49 \pm 7.36$ & $99.89 \pm 10.11$ & $<\mathbf{0 . 0 0 1}$ \\
$\mathbf{7 .}$ & WHR & $0.91 \pm 0.14$ & $0.96 \pm 0.12$ & $\mathbf{0 . 0 0 5}$ \\
$\mathbf{8 .}$ & Leptin $(\mathrm{pg} / \mathrm{ml})$ & $3.75 \pm 1.84$ & $6.89 \pm 2.46$ & $<\mathbf{0 . 0 0 1}$ \\
\hline
\end{tabular}

Pearson correlation analysis was done to assess association between the variables. Genotypic distribution was analyzed for Hardy-Weinberg equilibrium (HWE) and genetic variants for LEPR gene A668G, A326G and G1968C for obese and controls female were compared by chisquare $\left(\chi^{2}\right)$ analysis. All of the tests were performed using SPSS version 19.0 software. $\mathrm{P}<0.05$ was considered as statistically significant.

\section{Results}

The anthropometric data and leptin level of all the subjects are summarized in Table 1 . The anthropometric parameters are slightly higher in obese cases as compared to control group but the p-value is found no significant whereas, waist circumference and hip circumference shows a significant $\mathrm{p}$ - value $(\mathrm{p}<0.005)$ between cases and controls. The leptin level is found increased in obese cases than controls and this difference is significant with $\mathrm{p}<0.05$.

Genotype and allelic frequency of LEPR gene (Gln223Arg), (Lys109Arg) and (Lys656Asn) in the obese cases and control groups is given in Table-2. The higher frequency of GG genotype of (Gln223Arg) variant in obese cases with significant difference found in between obese cases and control groups $p<0.001$. Similarly GG and CC genotype of (Lys109Arg) and (Lys656Asn) respectively found higher frequency with significantly different $\mathrm{p}<0.001$ in obese group as compared to control group. When all these 3 LEPR genetic variants compared using Hardy-Weinberg Equation, the significant difference in the frequency of genotype was found.

Genetic variants of LEPR gene (Gln223Arg), (Lys109Arg) and (Lys656Asn) were correlated with anthropometric parameters i.e., obesity (non obese and obese) and leptin (low and high) level in the obese cases and control groups shown in Table 3. On comparing between controls and cases, the $\chi^{2}$ test showed significant $(\mathrm{p}<0.05$,

Table 2

Distribution of leptin receptor gene variants among cases and controls.

\begin{tabular}{|c|c|c|c|c|c|}
\hline Genetic variant & $\begin{array}{l}\text { Genotype/ } \\
\text { Allele } \\
\text { frequency }\end{array}$ & $\begin{array}{l}\text { Controls } \\
(\mathrm{n}=109) \\
(\%)\end{array}$ & $\begin{array}{l}\text { Cases } \\
(\mathrm{n}=120)(\%)\end{array}$ & $\chi^{2}$ value & $P$ value \\
\hline \multirow[t]{5}{*}{ LEPR Gln223Arg } & $\mathrm{AA}$ & $67(61.5)$ & $42(35.0)$ & 17.16 & $<0.001$ \\
\hline & AG & $34(31.2)$ & $56(46.7)$ & & \\
\hline & GG & $8(7.3)$ & $22(18.3)$ & & \\
\hline & Minor (A) & $\begin{array}{l}168 \\
(77.1)\end{array}$ & $140(58.3)$ & 18.20 & $<0.001$ \\
\hline & Major (G) & $50(22.9)$ & $100(41.7)$ & & \\
\hline \multirow[t]{5}{*}{ LEPR Lys109Arg } & $\mathrm{AA}$ & $52(47.7)$ & $31(25.8)$ & 17.48 & $<0.001$ \\
\hline & AG & $45(41.3)$ & $53(44.2)$ & & \\
\hline & GG & $12(11.0)$ & $36(30.0)$ & & \\
\hline & Minor (A) & $\begin{array}{l}149 \\
(68.3)\end{array}$ & 115 (47.9) & 19.53 & $<0.001$ \\
\hline & Major (G) & 69 (31.7) & $125(52.1)$ & & \\
\hline \multirow[t]{5}{*}{ LEPR Lys656Asn } & (GG) & $58(53.2)$ & $31(25.8)$ & 19.47 & $<0.001$ \\
\hline & (GC) & $42(38.5)$ & $65(54.2)$ & & \\
\hline & (CC) & $9(8.3)$ & $24(20.0)$ & & \\
\hline & Minor (G) & $\begin{array}{l}158 \\
(72.5)\end{array}$ & 127 (52.9) & 18.60 & $<0.001$ \\
\hline & Major (C) & $60(27.5)$ & $113(47.1)$ & & \\
\hline
\end{tabular}


Table 3

Correlation of leptin receptor gene polymorphisms with Leptin level and obesity.

\begin{tabular}{|c|c|c|c|c|c|c|c|}
\hline \multirow[t]{2}{*}{ SNP } & \multirow[t]{2}{*}{ Leptin } & \multirow[t]{2}{*}{ Group } & \multicolumn{3}{|l|}{ Genotype } & \multirow[t]{2}{*}{$\chi^{2}$ value } & \multirow[t]{2}{*}{$\mathrm{P}$ value } \\
\hline & & & Wild (\%) & Heterozygous (\%) & Mutant (\%) & & \\
\hline \multirow[t]{4}{*}{ LEPR Gln223Arg } & \multirow[t]{2}{*}{ Low } & Controls $(\mathrm{n}=71)$ & $40(56.3)$ & $24(33.8)$ & $7(9.9)$ & \multirow[t]{2}{*}{1.37} & \multirow[t]{2}{*}{0.505} \\
\hline & & Cases $(n=40)$ & $21(52.5)$ & $12(30.0)$ & $7(17.5)$ & & \\
\hline & \multirow[t]{2}{*}{ High } & Controls $(n=38)$ & $27(71.1)$ & $10(26.3)$ & $1(2.6)$ & \multirow[t]{2}{*}{22.28} & \multirow[t]{2}{*}{$<0.001$} \\
\hline & & Cases $(n=80)$ & $21(26.3)$ & $44(55.0)$ & $15(18.8)$ & & \\
\hline \multirow[t]{4}{*}{ LEPR Lys109Arg } & \multirow[t]{2}{*}{ Low } & Controls $(n=71)$ & 35 (49.3) & 31 (43.7) & $5(7.0)$ & \multirow[t]{2}{*}{7.16} & \multirow[t]{2}{*}{0.028} \\
\hline & & Cases $(n=40)$ & $17(42.5)$ & $13(32.5)$ & $10(25.0)$ & & \\
\hline & \multirow[t]{2}{*}{ High } & Controls $(\mathrm{n}=38)$ & $17(44.7)$ & $14(36.8)$ & $7(18.4)$ & \multirow[t]{2}{*}{10.08} & \multirow[t]{2}{*}{0.006} \\
\hline & & Cases $(n=80)$ & $14(17.5)$ & $40(50.0)$ & $26(32.5)$ & & \\
\hline \multirow[t]{4}{*}{ LEPR Lys656Asn } & \multirow[t]{2}{*}{ Low } & Controls $(n=71)$ & $39(54.9)$ & $26(36.6)$ & $6(8.5)$ & \multirow[t]{2}{*}{8.07} & \multirow[t]{2}{*}{0.018} \\
\hline & & Cases $(n=40)$ & $11(27.5)$ & $25(62.5)$ & $4(10.0)$ & & \\
\hline & \multirow[t]{2}{*}{ High } & Controls $(\mathrm{n}=38)$ & $19(50.0)$ & $16(42.1)$ & $3(7.9)$ & \multirow[t]{2}{*}{9.08} & \multirow[t]{2}{*}{0.011} \\
\hline & & Cases $(n=80)$ & $20(25.0)$ & $40(50.0)$ & $20(25.0)$ & & \\
\hline \multicolumn{8}{|l|}{ Obesity } \\
\hline \multirow[t]{4}{*}{ LEPR Gln223Arg } & \multirow[t]{2}{*}{ Non obese } & Controls $(\mathrm{n}=70)$ & $46(65.7)$ & $17(24.3)$ & $7(10.0)$ & \multirow[t]{2}{*}{6.88} & \multirow[t]{2}{*}{0.032} \\
\hline & & Cases $(n=77)$ & $34(44.2)$ & $31(40.3)$ & $12(15.6)$ & & \\
\hline & Obese & Controls $(\mathrm{n}=39)$ & $21(53.8)$ & $17(43.6)$ & $1(2.6)$ & 14.56 & 0.001 \\
\hline & & Cases $(n=43)$ & $8(18.6)$ & $25(58.1)$ & $10(23.3)$ & & \\
\hline LEPR Lys109Arg & Non obese & Controls $(\mathrm{n}=70)$ & $40(57.1)$ & $25(35.7)$ & $5(7.1)$ & 10.42 & 0.005 \\
\hline & & Cases $(n=77)$ & $27(35.1)$ & $32(41.6)$ & $18(23.4)$ & & \\
\hline & Obese & Controls $(n=39)$ & $12(30.8)$ & $20(51.3)$ & $7(17.9)$ & 8.69 & 0.013 \\
\hline & & Cases $(n=43)$ & $4(9.3)$ & $21(48.8)$ & $18(41.9)$ & & \\
\hline LEPR Lys656Asn & Non obese & Controls $(\mathrm{n}=70)$ & $42(60.0)$ & $24(34.3)$ & $4(5.7)$ & 20.76 & $<0.001$ \\
\hline & & Cases $(n=77)$ & $18(23.4)$ & $47(61.0)$ & $12(15.6)$ & & \\
\hline & Obese & Controls $(\mathrm{n}=39)$ & $16(41.0)$ & $18(46.2)$ & $5(12.8)$ & 3.01 & 0.223 \\
\hline & & Cases $(n=43)$ & $13(30.2)$ & 18 (41.9) & $12(27.9)$ & & \\
\hline
\end{tabular}

$\mathrm{p}<0.01$ and $\mathrm{p}<0.001$ ) association (correlation) of all genetic variants with high Leptin. However, both LEPR Lys109Arg and LEPR Lys656Asn SNPs also showed significant $(\mathrm{p}<0.05)$ with low Leptin. In all significant associations, the frequency of mutant genotype was higher in cases than controls. Similarly, on comparing between controls and cases, the $\chi^{2}$ test showed significant ( $\mathrm{p}<0.05$ or $\mathrm{p}<0.01$ or $\mathrm{p}<0.001$ ) association (correlation) of all SNPs with obesity (obese group) except LEPR Lys656Asn. However, LEPR Gln223Arg, LEPR Lys109Arg and LEPR Lys656Asn SNPs also showed significant ( $\mathrm{p}<0.05$ or $\mathrm{p}<0.01$ or $\mathrm{p}<0.001$ ) with non obesity (non obese group). In all significant associations, the frequency of mutant genotype was higher in cases than controls.

\section{Discussion}

In our study, we demonstrated a significant difference in the anthropometric data of obesity and an increase leptin level between obesity cases and control group. A significant rise of leptin level was found in obese group as compared to control group. This might be caused by LEPR resistant and also results in altered leptin binding and therefore, receptor dimerisation and signalling capacity of the leptin receptor. Moreover, waist hip ratio significantly different in obese cases as compared to control. These results are consistent with some studies as obesity was associated with higher leptin level. ${ }^{17,18}$ Whereas, some study contradicted our results and shown that obesity was not associated with higher leptin level. ${ }^{19}$ The leptin gene receptor is polymorphic, which means that in different subjects, differences in genetic variants may be found. However, such mutations are extremely rare and are not likely to be responsible for the obesity, because there are many factors that involved and contribute to the appearance of obesity. ${ }^{20}$ A study was done by Han et al. Showed a significant association between genotype and all parameters (age, weight and BMI) in females group, ${ }^{21}$ who reported that LYS109ARG polymorphism was strongly associated with BMI in Korean female populations which disagree with our findings of study. In Indian population, all three genetic variants (Gln223Arg), (Lys109Arg) and (Lys656Asn) showed different frequency (0.18), (0.30) and $(0.20)$, which found similar to results of one metaanalysis showed 0.25 of LEPR Lys109Arg in nine different Caucasian populations, 0.82 frequency for Korean and Japanese subjects. Similarly our frequency for 0.18 (Gln223Arg) in Indian population was similar to Pima Indians (0.32), and (0.45) and (0.85) in Caucasian or Asian population respectively. On the other hand, research by de Oliveira $^{18}$ found LEPR Lys109Arg to be correlated with reduced risk of obesity whereas in our study it shows high risk of obesity. Another research studies was done in reference to (Gln223Arg) in Tehran 0.15 ${ }^{21}, 0.156$ in Spain ${ }^{22}, 0.169$ in Brazilian, ${ }^{23} 0.18$ in Kuala Lumpur, ${ }^{24}$ 0.227 in Jeddah city, ${ }^{25} 0.287,0.261$ and 0.412 respectively in Malay, Chinese and Indian ethnics of Malaysian population, ${ }^{26}$ supports our study. Research done in Caucasian ${ }^{27}$ and Asian ${ }^{24,25}$ population, contrary to our data and showed that genetic variant of Gln223Arg was not associated with obesity and leptin level. Mutations in the leptin gene and the leptin gene receptor may lead to extreme obesity, this was found to be true in mice by Chen et al., ${ }^{28}$ and in humans by Clement et al. ${ }^{29}$ They found, that the presence of a homozygous mutations in the leptin gene (homozygotes ob/ob) and also homozygous mutations in the leptin gene receptor (homozygotes $\mathrm{db} / \mathrm{db}$ ) were associated with early onset of extreme obesity due to hyperphagia, poor energy expenditure and severe insulin-resistance. ${ }^{28,29}$ These studies gave rise to the idea that several genotypes of the leptin gene and its receptor may lead to obesity. In the Spanish population agreed with our results, the leptin gene receptor variants (Gln223Arg) can also be associated with obesity, similar results were obtained for Brazilian population. ${ }^{30}$

These Variations were found due to different ethnic rays in different study in different country due to and population. A large no. of sample size also required to use as biomarker of LEPR genetic variants and leptin level in obesity and unexplained infertility.

\section{Conclusion}

Genetic variants (Gln223Arg), (Lys109Arg) and (Lys656Asn) in LEPR gene are significantly associated with anthropometric parameter obesity and leptin level in northern Indian population with unexplained infertility. So, the present study concluded that these LEPR gene variants with obesity and higher leptin level could be as risk factor for unexplained infertility in Indian population. 


\section{Declaration of competing interest}

All the Authors declare that they have no conflict of interest.

\section{Acknowledgement}

The authors would like to acknowledged to Department of Science and Technology (DST) India, for providing funding support for this study. The Funding ID is DST/2012/30 dated 17August2012 . We would also like to thanks the Department of Biochemistry, K.G.M.U. Lucknow, for wet lab work of the study.

\section{References}

1. Arslan Nur, Erdur Baris, Aydin Adem. Hormones and cytokines in childhood obesity. Indian Pediatr. 2010;47(10):829-839.

2. Malnick SDH, Knobler H. The medical complications of obesity. Q J Med. 2006;99(9):565-579.

3. Zhang Y, Proenca R, Maffei M. Positional cloning of the mouse obese gene and its human homologue. Nature. 1994;372:425-432.

4. Munzberg H, Bjornholm H, Bates SH, Myers MG. Leptin receptor action and mechanisms of leptin resistance. Cell Mol Life Sci. 2005;62:642-652.

5. Bates SH, Myers MG. The role of leptin receptor signaling in feeding and neuroendocrine function. Trends Endocrinol Metab. 2003;14:447-452.

6. Shimizu H, Oh IS, Okada S. Leptin resistance and obesity. Endocr J. 2007;54:17-26.

7. Niki T, Mori H, Tamori Y. Human obese gene: molecular screening in Japanese and Asian Indian NIDDM patients associated with obesity. Diabetes. 1996;45:675-678.

8. Maffei M, Stoffel M, Barone M. Absence of mutations in the human ob gene in obese/ diabetic subjects. Diabetes. 1996;45:679-681.

9. Mammes O, Betoulle D, Aubert R, Giraurd V, Tuzet S, Fumeron F. Polymorphisms of the ob gene in human obesity. Int J Obes Relat Metab Disord. 1997;21:11.

10. Paracchini Valentina, Pedotti Paola, Taioli Emanuela. Human genome epidemiology (huge) review, genetics of leptin and obesity: a huge review. Am J Epidemiol. 2005; 162:101-114.

11. Tsiotra PC, Pappa V, Raptis SA, Tsigos C. Expression of the long and short leptin receptor isoforms in peripheral blood mononuclear cells: implications for leptin's actions. Metabolism. 2000;49:1537-1541.

12. Baratta M. Leptin - from a signal of adiposity to a hormonal mediator in peripheral tissues. Med Sci Monit. 2002;8:282-292.

13. Couce ME, Burquera B, Paresi JE, Jensen MD, Lloyd RV. Localization of leptin receptor in the human brain. Neuroendocrinology. 1997;66:145-150.

14. Lee GH, Proenca R, Montez JM. Abnormal splicing of the leptin receptor in diabetic mice. Nature. 1996;379:632-635.
15. Mantzoros CS. The role of leptin in human obesity and disease: a review of current evidence. Ann Intern Med. 1999;130:871-881.

16. Perez-Perez N. Flora san chez-jimenez, julieta maymo, jose L. Duenas, cecilia varone and victor san chez-margalet. Role of leptin in female reproduction. Clin Chem Lab Med. 2015;53(1):15-28.

17. Guizar-Mendoza JM, Amador-Licona N, Flores-Martınez SE, Lopez-Cardona MG Ahuatzin-Tremary R, Sanchez-Corona J. Association analysis of the Gln223Arg polymorphism in the human leptin receptor gene, and traits related to obesity in Mexican adolescents. J Hum Hypertens. 2005;19(5):341-346.

18. De Oliveira R, Cerda FD, Sampaio MF, Armaqanijan D, Bernik MM, Dorea EL. Leptin receptor gene polymorphisms are associated with adiposity and metabolic alterations in Brazilian Individuals. Arq Braz Endocrinol Metab. 2013;57(9):667-689.

19. Komsu-Omek Z, Demirel F, Dursum A, Emis B, Piskin Bideci A. Leptin Receptor gene Gln223 Arg polyorphism is not associated with obesity and metabolic syndrome in Turkish children. Turk J Pediatr. 2012;54:20-24.

20. Han HR, Ryu HJ, Cha HS, et al. Genetic variations in the leptin and leptin receptor genes are associated with type 2 diabetes mellitus and metabolic traits in the Korean female population. J of Clin Genetics. 2008;74:105-115.

21. Bender N, Allemann N, Marek D, et al. Association between variants of the leptin receptor gene (LEPR) and overweight: a systematic review and an analysis of the CoLaus study. PLoS ONE J. 2011;6(10):1-14.

22. Karimi K, Arkani M, Safaei A, Pourhoseingholi MA, Mohebbi SR, Fatemi SR. Association of leptin receptor gene Gln223Arg polymorphism with susceptibility to colorectal cancer. Gastroenterol Hepatol Bed Bench. 2011;4(4):192-198.

23. Mattevi VS, Zembrzuski VM, Hutz MH. Association analysis of genes involved in the leptin-signaling pathway with obesity in Brazil. Int J Obes Relat Metab Disord. 2002;26(9):1179-1185.

24. Liew S, Chuah H, Lau C, Lee C, Say Y. Prevalence of the leptin receptor gene variations and obesity risk factors among Malaysian university students of Setapak Kuala Lumpur. Asian J Epidemiol. 2009;2:49-58.

25. Linjawi SA, Husain NA. Impact of leptin receptor gene Gln223Arg polymorphism on obesity in Jeddah City. Life Sci J. 2012;9(4):818-828.

26. Etemad A, Ramachandran V, Pishva SR, et al. Analysis of Gln223Arg polymorphism of leptin receptor gene in type II diabetes mellitus subjects among Malaysians. Int $J$ Mol Sci. 2013;14:19230-19244.

27. Jonathan PC, Jeronimo L, Brenda C, Claudia B, Absalom Z, Cesar RG. 2548A leptin receptor and Q223R leptin receptor polymorphisms in obese Mexican subjects. Am J Agric Biol Sci. 2013;8(1):34-43.

28. Chen H, Charlat O, Tartaglia LA. Evidence that the diabetes gene encodes the leptin receptor: identification of a mutation in the leptin receptor gene in $\mathrm{db} / \mathrm{db}$ mice. Cell. 1996;84:491-495.

29. Clement K, Vaisse C, Lahlou N, et al. A mutation in the human leptin receptor gene causes obesity and pituitary dysfunction. Nature. 1998;392:398-401.

30. Duarte SF, Francischetti EA, Genelhu-Abreu V. Q223R leptin receptor polymorphism associated with obesity in Brazilian multiethnic subjects. Am J Hum Biol. 2006;18:448-453. 